\title{
Clinical features and hormonal profiles of cloprostenol-induced early abortions in heifers monitored by ultrasonography Fikre Lobago ${ }^{1,3}$, Hans Gustafsson², Merga Bekana³, Jean-François Beckers ${ }^{4}$ and Hans Kindahl*1
}

\author{
Address: ${ }^{1}$ Department of Clinical Sciences, Faculty of Veterinary Medicine and Animal Science, Swedish University of Agricultural Sciences, Box \\ 7054, SE-750 07, Uppsala, Sweden, 2Swedish Dairy Association, SE-63184, Uppsala, Sweden, ${ }^{3}$ Faculty of Veterinary Medicine, Addis Ababa \\ University, P.O. Box 34, Debre Zeit, Ethiopia and ${ }^{4}$ Department of Physiology of Animal Reproduction, Faculty of Veterinary Medicine, University \\ of Liège, Liège, Belgium \\ Email: Fikre Lobago - fikre_lobago@yahoo.com; Hans Gustafsson - hans.gustafsson@kv.slu.se; Merga Bekana - margabekana@yahoo.com; Jean- \\ François Beckers - jfbeckers@ugl.ac.be; Hans Kindahl* - hans.kindahl@kv.slu.se \\ * Corresponding author
}

Published: 23 November 2006

Acta Veterinaria Scandinavica 2006, 48:23 doi:10.1 186/175I-0147-48-23

This article is available from: http://www.actavetscand.com/content/48/I/23

(C) 2006 Lobago et al; licensee BioMed Central Ltd.

This is an Open Access article distributed under the terms of the Creative Commons Attribution License (http://creativecommons.org/licenses/by/2.0), which permits unrestricted use, distribution, and reproduction in any medium, provided the original work is properly cited.
Received: 14 November 2006

Accepted: 23 November 2006

\begin{abstract}
Background: The present study describes the clinical features and plasma profiles of bovine pregnancy-associated glycoprotein I (bPAGI), the main metabolite of prostaglandin $F_{2 \alpha}$ (PG metabolite) and progesterone (P4) in heifers in which early abortions were induced.

Methods: Early abortions were induced in four heifers with cloprostenol and monitored by ultrasonography. Blood samples were collected and the plasma were analyzed for bPAG I, P4 and PG metabolite.

Results: The foetal heartbeat rates varied from 170-186 beats per minute for all foetuses up to the date of cloprostenol treatment. Foetal death was confirmed within two days after cloprostenol treatment. Prior to cloprostenol injection, blood plasma concentrations of bPAGI, PG metabolite and P4 varied from $8.4-40.0 \mathrm{ng} / \mathrm{mL}, 158-275 \mathrm{pmol} / \mathrm{L}$ and $20.7-46.9 \mathrm{nmol} / \mathrm{L}$, respectively. After the foetus expelled, the plasma level of bPAGI began to decrease but the decrease was small and gradual. The estimated half-life of bPAG I was $1.8-6.6$ days. The plasma level of the PG metabolite started to have short lasting peaks (above $300 \mathrm{pmol} / \mathrm{L}$ ) within three hours after cloprostenol treatment. The plasma concentrations of P4 dropped sharply to less than $4 \mathrm{nmol} / \mathrm{L}$ after 24 hours of cloprostenol injection.

Conclusion: The current findings indicated that after early closprostenol-induced foetal death, the plasma concentration of bPAGI decreased gradually and showed a tendency of variation with the stages of pregnancy.
\end{abstract}

\section{Background}

The isolation and characterization of pregnancy-specific protein B (PSPB) [1] or bovine pregnancy-associated glycoprotein 1 (bPAG1)[2] in the cow by immunoelectro- phoresis and the subsequent development of RIA techniques for this protein (for PSPB[3] and for bPAG1[4]) enabled hormonal diagnosis of pregnancy in cattle. Detection of PSPB/bPAG1 in the maternal blood 
can be a good indicator of pregnancy and foeto-placental viability $[5,6]$. PSPB/bPAG1 is detected at around 24 days post conception and reaches a peak at approximately the time of parturition and drops after calving but it is detectable for up to 3 months in postpartum cows $[3,4,7]$.

In early (between 30-50 days of pregnancy) abortions induced both by experimental Arcanobacterium pyogens infection and by natural prostaglandin $\mathrm{F}_{2 \alpha^{\prime}}$ the plasma concentration of PSPB fell steadily from the day of inoculation/treatment but the levels remained above the threshold with a half-life time of 7 days. In terms of detecting embryonic loss following infection, monitoring PSPB on a regular basis has advantages over the assessment of progesterone concentration [5]. Thus PSPB/ bPAG1 analysis could be used as an alternative test to determine pregnancy after 30 days post breeding but its relative long half-life ( $7-8$ days, $[5,8])$, imposes limitations especially in post partum cows and in cows after embryonic/foetal mortality.

In cloprostenol induced early abortions in heifers, the clinical features and patterns of prostaglandin $\mathrm{F}_{2 \alpha}$ metabolite (PG metabolite) were categorized into two: after 100 days and before 75 days of pregnancy stages [9]. The heifers in the former group had retained foetal membranes and delayed return to cyclicity and heat whereas heifers in the latter group expelled their foetuses with intact foetal membranes and showed standing heat within three days after injection. Although most pregnancy failures occur due to embryonic/early foetal mortality up to 50 days post breeding, foetal mortality occurs to some extent until 90 days of pregnancy $[10,11]$. Detailed information about clinical features and plasma profiles of PSPB/bPAG1 and PG metabolite after induced or spontaneous foetal mortality for pregnancy stages after 60 days (for PSPB/bPAG1) and between 75-90 days (for PG metabolite) in cattle is sparse.

Accurate pregnancy diagnosis could be achieved based on the recognition of a proper embryo with a beating heart, between 26 and 34 days, by use of ultrasonography in cattle [12]. Moreover, embryonic mortality could be estimated at an earlier stage by ultrasound investigation than by PSPB or progesterone assays $[5,13]$. Thus ultrasound could be used to monitor embryonic/foetal viability and consequently to determine the time of embryo/foetal mortality in induced or spontaneous abortions in cattle. Therefore, the present study describes the clinical features and plasma profiles of bPAG1, PG metabolite and progesterone in heifers after cloprostenol induced early abortions (between 60 and 120 days of pregnancy) monitored by ultrasonography.

\section{Methods \\ Experimental animals}

Four Swedish Red and White Breed (SRB) heifers (numbered 1-4) were used. The first three heifers were 24 months old while the fourth one was 21 months old at the beginning of the experiment. They were fed according to the Swedish standard and their rectal temperature and clinical status were regularly checked. The experiment was done, with the approval of the local ethical committee, at the Department of Clinical Sciences, Swedish University of Agricultural Sciences, Uppsala.

\section{Experimental protocol}

Heifers were inseminated following standing heat. Heifer4 conceived on the first insemination whereas heifers 2 and 3 on the second and heifer- 1 on the third consecutive inseminations. A transrectal ultrasonography (5 MHz linear array transducer; Aloka SSD-210 DXII, Aloka Co., Tokyo, Japan) was used to confirm pregnancy and monitor embryo/foetal viability. Embryo/foetus viability was monitored once weekly until 7 days before cloprostenol treatment and then daily till foetal death/abortion occurred. Heartbeat rate was determined by counting the number of heartbeats from the video tape recording of the ultrasonographic examinations as described previously [14]. The heifers were given one intramuscular injection of $500 \mu \mathrm{g}$ of a prostaglandin analogue (cloprostenol, Estrumate $^{\circledast}$, Schering-Plough, Stockholm, Sweden) to induce luteolysis and subsequent foetal death and abortion. At the time of cloprostenol treatment, heifers 1, 2, 3 and 4 were at pregnancy stages of 63, 77, 83 and 116 days, respectively.

Blood samples were collected from the jugular vein starting one week before cloprostenol treatment. The collection was performed by venipuncture every day for the first five days followed by every three hours from two days before until five days post cloprostenol treatment. Two further blood samples were collected on the $7^{\text {th }}$ and $9^{\text {th }}$ days post cloprostenol injection. The blood samples were drawn into heparinized vacuum tubes and centrifuged immediately. The plasma was removed and stored at $20^{\circ} \mathrm{C}$ until analysed.

\section{Hormone analysis}

Those plasma samples collected two days before and fives days post cloprostenol treatment were analysed for PG while the daily (the first five days and the last two days) and every six hours (two days before and five days post cloprostenol treatment) plasma samples were analysed for P4 and bPAG1. The Plasma samples were analyzed for concentrations of progesterone [15] and PG metabolite [16] according to the radioimmunoassay methods previously described. Whereas bPAG1 analysis was done following the techniques initially described [4] with little 
modification as described briefly hereunder. As an assay buffer 25 mM Tris HCl, pH 7.6 + 0.1\% bovine serum albumin was used throughout the procedure. Bovine ${ }^{125}$ I-PAG labelled according to the chloramine T method [17] was used as a tracer. Antiserum raised in rabbit against bPAG1 was used as the first antibody at an initial dilution of 1:150,000 whereas double antibody precipitation system was used to separate the bound complex.

For the standard curve lyophilized bPAG1 was diluted with assay buffer to get concentrations ranging from 0.78 to $100 \mathrm{ng} / \mathrm{mL}$ in a non-preincubated system. Of each standard concentration, $0.1 \mathrm{~mL}$ was added to duplicate tubes and diluted with $0.2 \mathrm{~mL}$ assay buffer and for the zero standards $\left(\mathrm{B}_{0}\right)$ and non-specific binding (NSB), only 0.3 and $0.4 \mathrm{~mL}$ of buffer, respectively was added. Bovine PAG free serum $(0.1 \mathrm{~mL})$ was added to all standard curve tubes. For the test plasma samples, duplicate tubes were labelled for each sample and $0.3 \mathrm{~mL}$ assay buffer was added to each tube including two more duplicate tubes for quality control. Then $0.1 \mathrm{~mL}$ of each test plasma sample and the two quality control sera was added to the respective duplicate tubes. Following this, $0.1 \mathrm{~mL}$ of tracer and first antibody were consecutively added to all tubes (except the first antibody for non-specific binding tubes) and mixed gently and incubated overnight at room temperature. A tracer $(0.1 \mathrm{~mL})$ alone was added to duplicate tubes for total count $(\mathrm{T})$. The second day, $1 \mathrm{~mL}$ of the double antibody precipitation system was added to all tubes except the T and incubated for further 30 minutes. After dilution with $2 \mathrm{~mL}$ of assay buffer, all tubes were centrifuged at $1500 \times \mathrm{g}$ for 20 minutes and the radioactivity of the pellet (discarding the supernatants) was counted by a gamma counter (LKB Wallac 1261; Wallac Turku, Finland) with a counting efficiency of $75 \%$. The binding ratio of the radiolabelled ${ }^{125}$ I-PAG to the antiserum was considered as $100 \%$ in the zero standard $\left(B_{0}\right)$ assay tube.

The sensitivity of the bPAG1 RIA was $1 \mathrm{ng} / \mathrm{mL}$ for the nonpreincubated system used. The intra-assay CV for two serum samples with known bPAG1 concentrations (mean $\pm \mathrm{SD}=2.5 \pm 0.3$ and $29.3 \pm 2.3 \mathrm{ng} / \mathrm{mL}$ ) each carried out twenty times were $10.8 \%$ and $8.2 \%$, respectively. While the inter-assay $\mathrm{CV}$ of low and high concentrations of bPAG1 quality control serum pools (mean $\pm \mathrm{SD}=9.2 \pm$ 0.4 and $50.3 \pm 3.0 \mathrm{ng} / \mathrm{mL}$ ) were 4.5 and $6.0 \%$, respectively.

\section{Determination of half-life for bPAGI}

Half-life for bPAG1 was estimated for the first three heifers and the fourth one starting from 2.3 and 4 days post cloprostenol injection, respectively, at which the fall in plasma bPAG1 concentration was commenced. The following formula was employed $[8,18]$ for the estimation. $\mathrm{T}_{1 / 2}=[\ln (\mathrm{C} / .5 \mathrm{C})] / \lambda$
Where $\mathrm{C}$ is the plasma concentration of bPAG1 at time zero, and $\lambda$ is the slope of the regression equation.

\section{Results}

\section{Clinical and ultrasonographic features}

Pregnancy was confirmed between 33 and 40 days postinsemination by detection of heartbeat of the embryo. The foetal heartbeat rates varied from 170-186 beats per minute for all foetuses up to the date of cloprostenol treatment. Foetal death (loss of heartbeat) was confirmed within two days after cloprostenol treatment. Two of the heifers (nos. 1 \& 2) had thick mucous vaginal discharge whereas the other two had blood tinged discharge on the second day post cloprostenol treatment. The dead foetuses were expelled within four days after cloprostenol treatment in three of the heifers whereas the fourth was trapped in the vagina and removed manually. There was no grossly visible abnormality in aborted foetuses at necropsy examination. Standing oestrus was observed in two of the heifers (nos. 1 \& 2) within two days after abortion. The detailed clinical and ultrasonographic features associated with cloprostenol induced early abortions are summarised in Table 1.

\section{Plasma hormonal profiles}

During one week prior to cloprostenol injection, the plasma concentrations of bPAG1, PG metabolite and progesterone varied from $8.4-40.0 \mathrm{ng} / \mathrm{mL}, 158-275 \mathrm{pmol} /$ $\mathrm{L}$ and 20.7 - $46.9 \mathrm{nmol} / \mathrm{L}$, respectively. The plasma bPAG1 concentrations were progressively increasing with minor irregularities in heifers 1 and 3 while the changes were irregular in the other two heifers during the oneweek period of blood sampled until cloprostenol treatment. Between cloprostenol treatment and expulsion of foetus, the plasma bPAG1 level did not fall but showed minor changes. After foetal expulsion, the plasma level of bPAG1 began to decrease but the decrease was small and gradual up to the last blood sample analysed (6-7 days after foetal expulsion). This decrease in plasma concentrations of bPAG1 was $65.3 \%, 57.5 \%, 55.3 \%$ and $45.6 \%$ for heifers $1-4$, respectively. The rate of decrease seems relatively slower with increasing pregnancy stage at the time of cloprostenol injection. On the basis of gradual decline of the plasma levels of bPAG1, a half-life ranging from 1.8 -6.6 days was estimated.

The plasma level of PG metabolite started to have short lasting peaks (above $300 \mathrm{pmol} / \mathrm{L}$ ) within three hours after cloprostenol treatment. Then it returned to the pre-treatment level after foetal mortality in the first two heifers (see Fig. 1 \&2) but the pulsatile release (above $300 \mathrm{pmol} / \mathrm{L}$ ) of PG metabolite continued up to the last blood sample analysed ( $5^{\text {th }}$ day post cloprostenol injection) in the other two heifers especially in the fourth heifer (see Fig. 3 \&4). 
Table I: Clinical and ultrasonographic features associated with cloprostenol induced early abortions in four Swedish Red and White heifers.

\begin{tabular}{|c|c|c|c|c|}
\hline Clinical/Ultrasonographic Features & Heifer-I & Heifer-2 & Heifer-3 & Heifer-4 \\
\hline Stages of gestation* (days) & 63 & 77 & 83 & 116 \\
\hline Heartbeat rate (beats per minute) & $170-182$ & $178-186$ & $180-184$ & $176-182$ \\
\hline Foetal death post-CP treatment (Hrs) & $<24$ & $<24$ & $24-48$ & $24-48$ \\
\hline Foetus/FM expelled** (Hrs) & $56-72$ & $80-96$ & 75 & $80-96 \#$ \\
\hline CRL of expelled foetus $(\mathrm{cm})$ & 9 & 12 & 15 & 30 \\
\hline Foetus expelled with unruptured FM & Yes & Yes & Yes & No\# \\
\hline Thick mucous vaginal discharge & Yes & Yes & No & No \\
\hline Blood tinged vaginal discharge & No & No & Yes & Yes \\
\hline Showed standing heat*** & Yes & Yes & No & No \\
\hline
\end{tabular}

*on the day of cloprostenol treatment; **after cloprostenol treatment; *** within two days after abortion; \#only the foetal membrane was expelled but the foetus was stacked in the vagina and removed manually; $C P=$ cloprostenol; Hrs = hours; $C R L=$ crown-rump length; $F M=$ foetal membrane.

The plasma concentration of progesterone dropped sharply after the cloprostenol injection and was less than $4 \mathrm{nmol} / \mathrm{L}$ after 24 hours in all heifers. From the last plasma sample analysed, the progesterone concentration seems to rise again in the first three heifers (see Fig. 1, 2,
3) indicating resumption of ovarian cyclicity but it remained below detection in the fourth heifer (see Fig. 4).

\section{Discussion}

Because of the unpredictable occurrence of embryonic or foetal losses in a herd and the current increasing interest

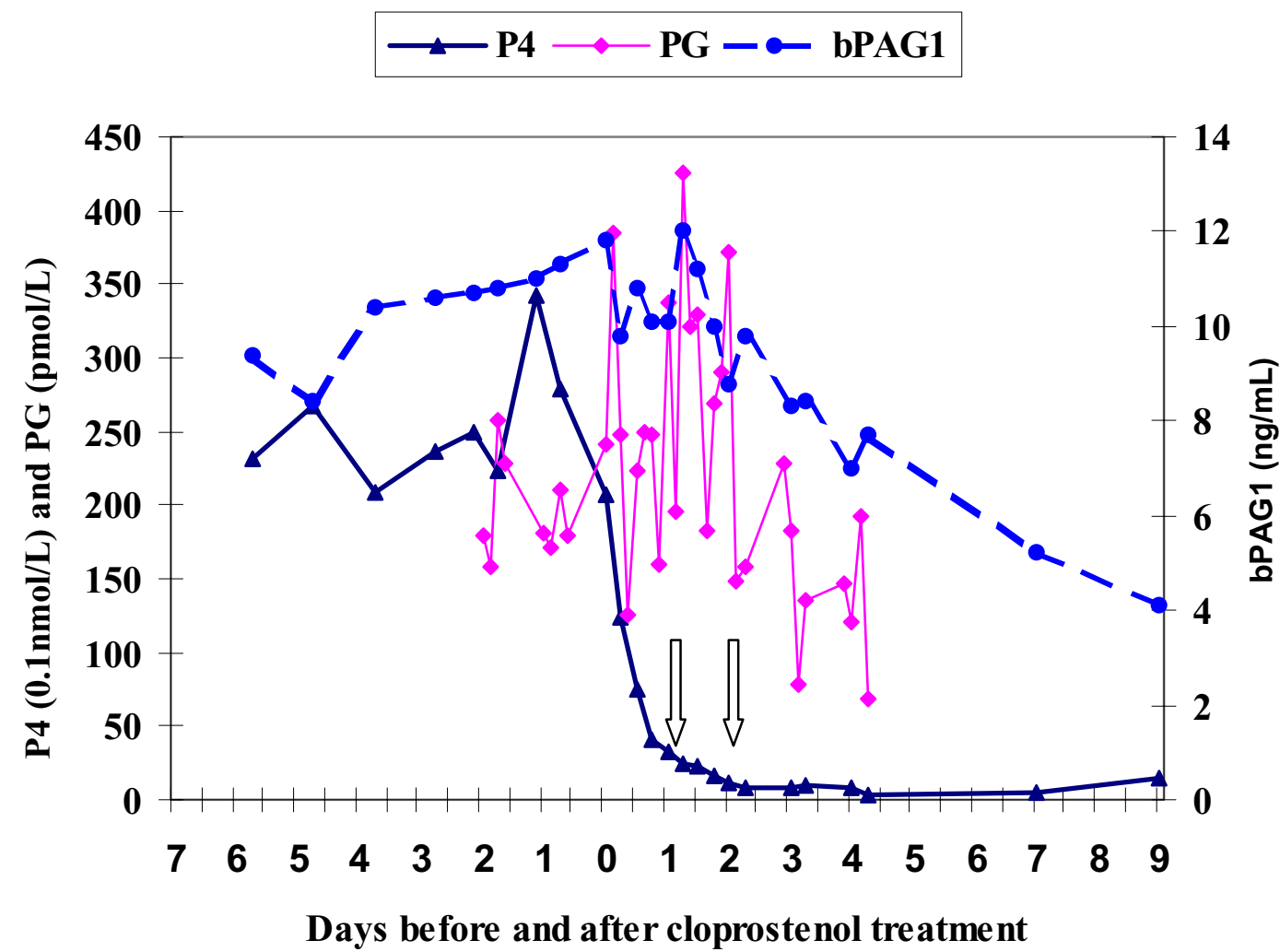

Figure I

Plasma profiles of bPAG I, P4 \& PG for Heifer-I before and after cloprostenol treatment on day 0 (63 days post insemination). Foetal death occurred between the two arrows. P4 = progesterone; bPAGI = bovine pregnancy associated glycoprotein I; PG = the main metabolite of prostaglandin $F_{2 \alpha}$ 


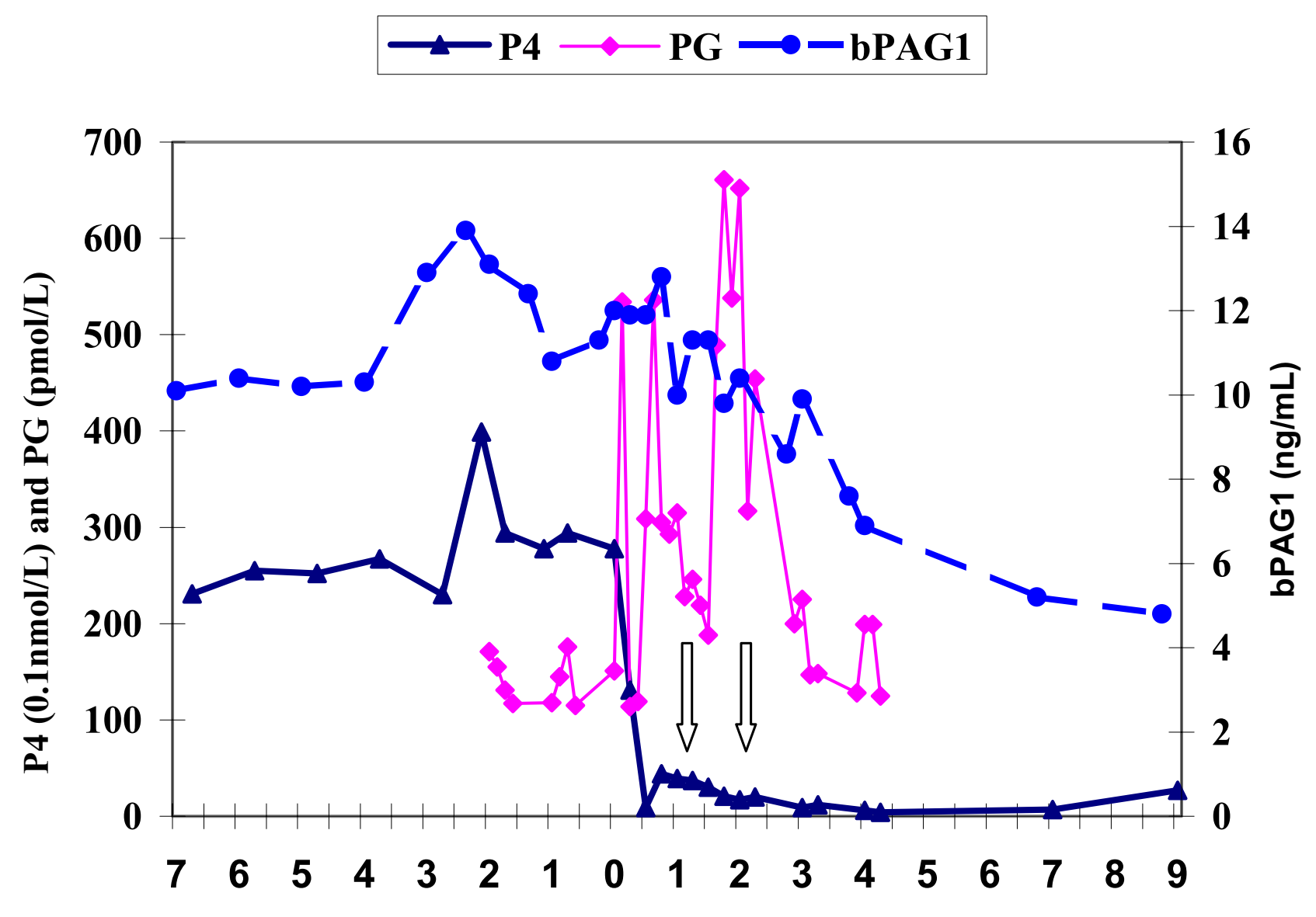

Days before and after cloprostenol treatment

Figure 2

Plasma profiles of bPAG I, P4 \& PG for Heifer-2 before and after cloprostenol treatment on day 0 (77 days post insemination). Foetal death occurred between the two arrows. P4 = progesterone; bPAGI = bovine pregnancy associated glycoprotein I; PG = the main metabolite of prostaglandin $F_{2 \alpha}$

of monitoring pregnancies in bovine, it is important to monitor pregnancies at early stage. One way to create a model of foetal death is to use drugs like cloprostenol that induce mortality.

Lindell and co-workers [9] induced abortions in heifers and found differences on physical nature of the abortions and PG metabolite release between two different stages of pregnancies (pregnancies below 75 days and between 100 - 150 days). In the former group foetuses were delivered with intact foetal membranes with little or no bleeding whereas in the latter group the aborted foetuses were delivered prior to the membranes, which were retained for more than 24 hours. The proposed reason for the differences in the nature of the induced abortions was the differences in the degree of foetal membrane attachment.
The findings of the present study are in agreement with the report of Lindell and co-workers [9], but heifer no. 3 is obviously falling between the two groups since she had blood tinged vaginal discharge and expelled foetus with intact foetal membrane.

Standing oestrus was observed in two of the heifers (nos. 1 \& 2) within two days after abortion supporting the suggestion given by Lindell and co-workers [9]. These authors suggested that abortion could be induced up to 80 days of pregnancy for practical reasons with little or no compromise at the subsequent reproductive performance at least in heifers. This is because such abortions are associated with only little or no uterine trauma. This idea is further supported by the return of PG metabolite release to the basal level immediately after abortion in these heifers 


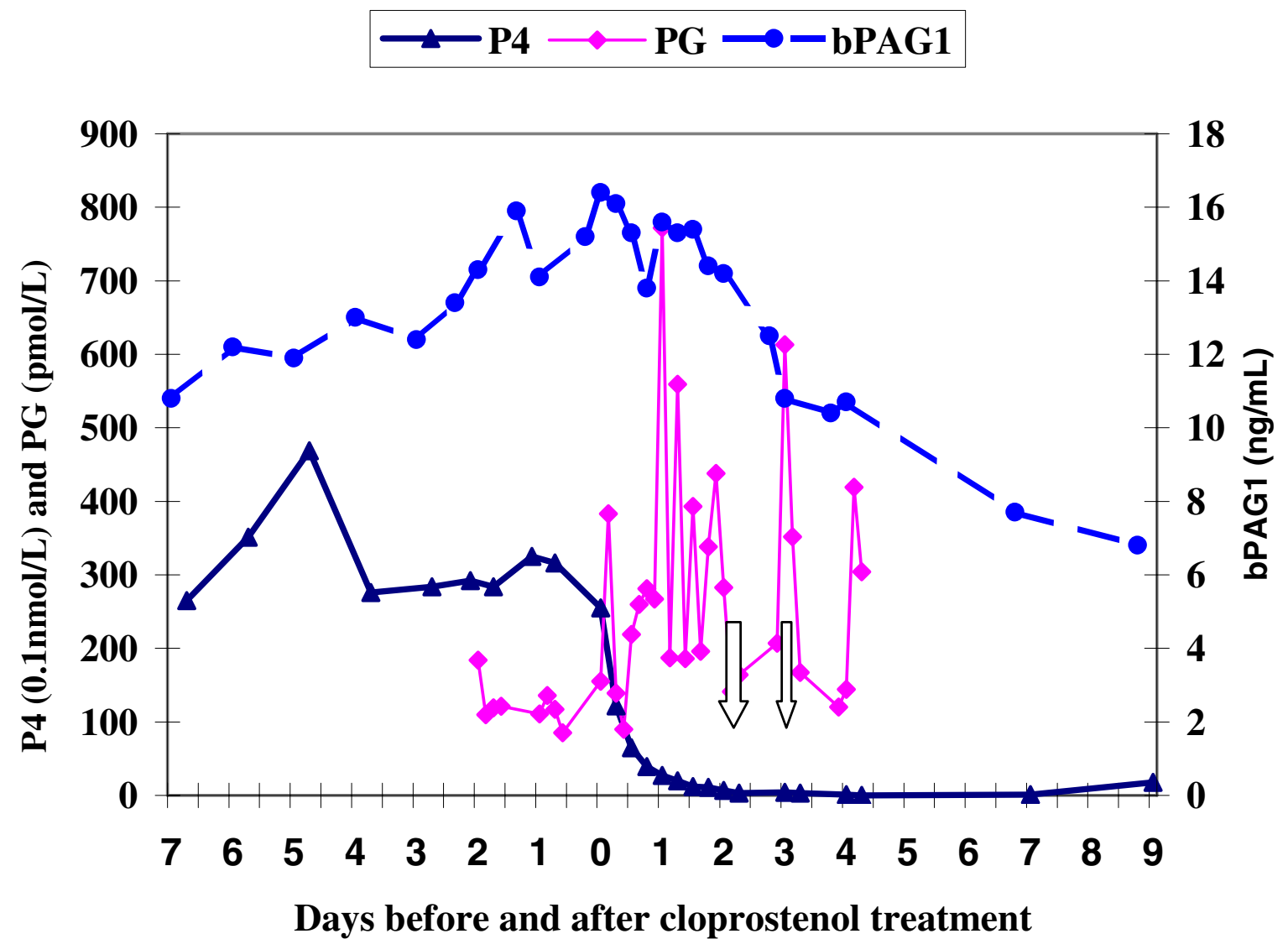

Figure 3

Plasma profiles of bPAGI, P4 \& PG for Heifer-3 before and after cloprostenol treatment on day 0 (83 days post insemination). Foetal death occurred between the two arrows. $\mathrm{P} 4=$ progesterone; $\mathrm{BPAGI}=$ bovine pregnancy associated glycoprotein I; PG = the main metabolite of prostaglandin $F_{2 \alpha}$

unlike those heifers above 100 days of pregnancy as it was observed by Lindell and co-workers [9] and the current study.

Detection of PSPB or bPAG1 above the threshold levels in the maternal blood of cows or heifers is a good indicator of the presence of a live embryo or foetus with the exceptions during the postpartum period or for few days after embryonic/foetal death $[5,6]$. Moreover, the plasma/ serum levels of PSPB/bPAG1 fell steadily commencing within 24 hours of inoculation/injection [5] or embryonic/foetal mortality [18] following experimental Arcanobacterium pyogens infection or cloprostenol injection. On the other hand, in the current study the gradual fall of plasma bPAG1 concentration commenced after 48 hours of cloprostenol treatment (after expulsion of the foetuses) in three of the heifers and even later in the fourth heifer.
The previous experiments involved heifers/cows at pregnancy stages less than 50 days whereas the current one above 60 days, which may explain the observed difference in the time of start of decline in plasma bPAG1 concentration. Szenci and co-workers [18] reported a half-life of 3.2 - 3.9 days of bPAG1 after cloprostenol induced embryonic mortality in heifers, which falls within the range of the current finding. Moreover, Semambo and co-workers [5] reported approximately seven days half-life of PSPB, which is roughly closer to the present finding. The minor differences observed in the half-life of bPAG1 among the reports of different workers may be due to differences in the stages of pregnancy at the time of induction of embryonic/foetal mortality. In the current study the plasma level of bPAG1 did not fall immediately after death of the foetus but it showed minor changes until the foetus was expelled. These minor changes in plasma bPAG1 concen- 


\section{$\longrightarrow$ P4 —PG — - bPAG1}

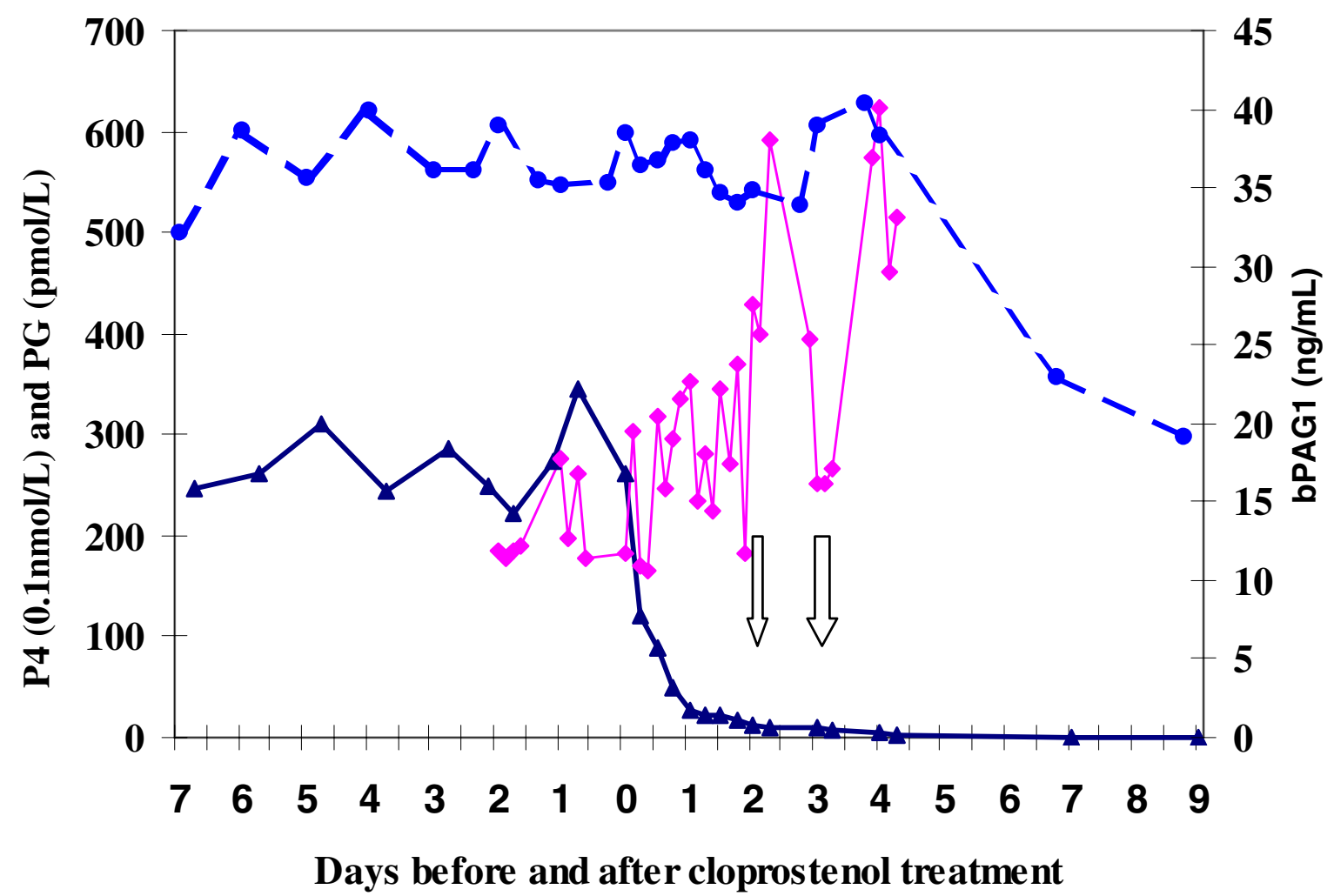

\section{Figure 4}

Plasma profiles of bPAG I, P4 \& PG for Heifer-4 before and after cloprostenol treatment on day 0 ( 1 I 6 days post insemination). Foetal death occurred between the arrows. P4 = progesterone; bPAGI = bovine pregnancy associated glycoprotein I; PG = the main metabolite of prostaglandin $F_{2 \alpha}$

tration could be possibly explained by the effect of uterine contraction caused by the pulsatile release of the endogenous $\mathrm{PGF}_{2 \alpha}$ (measured as the metabolite) and a continuity of the placental release of bPAG1 for a brief time even after foetal death. Moreover, the differences in the rate of decline of plasma bPAG1 concentration observed among the heifers at different stages of gestation period could also be possibly attributed to the increase in the plasma concentration and half-life of the glycoprotein with increasing stage of pregnancy.

The plasma PG metabolite level before cloprostenol treatment was in the basal level (below $300 \mathrm{pmol} / \mathrm{L}$ ) but the level increased immediately after the treatment, which agrees with the results of Lindell and co-workers [9]. How- ever, the reason behind such immediate rise of the peripheral blood level of endogenous PG metabolite after cloprostenol injection is not well established and it needs further investigation.

In heifer no. 4, the pulsatile release of PG metabolite continued up to five days post PG injection even after expulsion of the foetus though the highest concentration of PG metabolite was $623 \mathrm{pmol} / \mathrm{L}$. This plasma PG metabolite concentration is low as compared to the previous report of Lindell and co-workers [9], who reported massive release of PG metabolite up to $2500 \mathrm{pmol} / \mathrm{L}$ in heifers having the same pregnancy stage (heifer no. 4) at the time of abortion induced by cloprostenol. This difference in the level of PG metabolite could be partly attributed to the effect of 
retained foetal membranes in case of the latter heifer with higher level of PG metabolite. This is because cows with retained foetal membranes had significantly higher levels of PG metabolite than cows without retained foetal membranes during the immediate postpartum period [19].

In the current study, a sharp decline of plasma levels of progesterone (from above $20.7 \mathrm{nmol} / \mathrm{L}$ to less than 4 $\mathrm{nmol} / \mathrm{L}$ ) during 24 hours post cloprostenol injection was observed. This finding agrees with previous reports that indicated the luteolytic effect of cloprostenol in cyclic non-pregnant or pregnant cows/heifers [9,20-22]. In the present study, the disruption of foeto-endometrial connection as a result of contraction of the uterus caused by the pulsatile release of the endogenous PG metabolite could be the possible cause for the occurrence of foetal deaths within 24 to 48 hours after cloprostenol injection. Szenci and co-workers [18] reported the occurrence of late embryonic mortalities within 24 and between 48 and 72 hours post Arcanobacterium pyogens inoculation and cloprostenol treatment, respectively. In another cloprostenol induced abortion study, the progesterone concentration dramatically declined to $<0.5 \mathrm{ng} / \mathrm{mL}$ within 24 hours of treatment [5].

\section{Conclusion}

In conclusion, the results of the present study indicated that after early closprostenol-induced foetal death (at pregnancy stages between 60 and 120 days) the plasma concentration of bPAG1 decreased gradually and the rate of decrease showed a tendency of variation with the stages of pregnancy, which requires further confirmation. Moreover, the current finding supports the suggestion [9] that abortion could be successfully induced up to 80 days of pregnancy for practical reasons at least in heifers with little or no compromise to the subsequent reproductive performance.

\section{Competing interests}

The author(s) declare that they have no competing interests.

\section{Authors' contributions}

FL did the blood sampling, clinical and ultrasonographic examinations, laboratory analyses of samples, drafting and revision of the manuscript and participated in the planning of the experiment. HG participated in the planning and coordination of the experiment. MB took part in the planning of the experiment. JFB supervised the laboratory analyses of samples. HK participated in the planning and coordination of the experiment and supervised the laboratory analyses of samples. HG, MB, JFB and HK participated in the critical revision of the manuscript. All authors read and approved the final manuscript.

\section{Acknowledgements}

Sida/SAREC is acknowledged for a scholarship to Fikre Lobago and research grant for this study. The authors would like to thank the Department of Physiology of Animal Reproduction, University of Liège, Belgium, specially Dr. J Sulon, Head of the laboratory for providing facilities and expert advices for RIA of bPAGI and the section of Clinical Chemistry, SLU, Uppsala for RIA of progesterone.

\section{References}

I. Butler JE, Hamilton WC, Sasser RG, Ruder CA, Hass GM, Williams $\mathrm{RJ}$ : Detection and partial characterization of two bovine pregnancy-specific proteins. Biol Reprod 1982, 26:925-933.

2. Zoli AP, Beckers JF, W-Ballman P, Closset J, Falmagne P, Ectors F: Purification and characterization of a bovine pregnancyassociated glycoprotein. Biol Reprod I99I, 45: I- I0.

3. Sasser RG, Ruder CA, Ivani KA, Butler JE, Hamilton WC: Detection of pregnancy by radioimmunoassay of a novel pregnancyspecific protein in serum of cows and a profile of serum concentrations during gestation. Biol Reprod 1986, 35:936-942.

4. Zoli AP, Guilbault LA, Delahaut P, Ortiz WB, Beckers JF: Radioimmunoassay of a bovine pregnancy-associated glycoprotein in serum: its application for pregnancy diagnosis. Biol Reprod 1992, 46:83-92

5. Semambo DKN, Eckersall PD, Sasser RG, Ayliffe TR: Pregnancyspecific protein $B$ and progesterone in monitoring viability of the embryo in early pregnancy in the cow after experimental infection with Actinomyces pyogenes. Theriogenology 1992, 37:741-748.

6. Szenci O, Taverne MAM, Beckers JF, Sulon J, Varga J, Börzsönyi L, Hanzen Ch, Schekk Gy: Evaluation of false ultrasonographic diagnoses in cows by measuring plasma levels of bovine pregnancy-associated glycoprotein I. Vet Rec I998, I 42:304-306.

7. Humblot P, Camous S, Martal J, Charlery J, Jeanguyot N, Thibier M, Sasser G: Diagnosis of pregnancy by radioimmunoassay of a pregnancy-specific protein in the plasma of dairy cows. Theriogenology 1988, 30:257-267.

8. Kiracofe GH, Wright JM, Schalles RR, Ruder CA, Parish S, Sasser RG: Pregnancy-specific protein $B$ in serum of postpartum beef cows. J Anim Sci 1993, 71:2199-2205.

9. Lindell J-O, Kindahl H, Edqvist L-E: Prostaglandin induced early abortions in the bovine. Clinical outcome and endogenous release of prostaglandin $\mathbf{F}_{\mathbf{2} \alpha}$ and progesterone. Anim Reprod $\mathrm{Sci}$ 1980, 3:289-299.

10. Ayalon N: A review of embryonic mortality in cattle. J Reprod Fertil 1978, 54:483-493.

II. Peters AR, Ball PJH: Reproduction in cattle 2nd edition. Blackwell Science Ltd; I995: I-II.

12. Pieterse MC, Szenci O, Willemse AH, Bajcsy CSA, Dieleman SJ, Taverne MAM: Early pregnancy diagnosis in cattle by means of linear-array real-time ultrasound scanning of the uterus and a qualitative and quantitative milk progesterone test. Theriogenology 1990, 33:697-707.

13. Szenci O, Beckers JF, Humblot P, Sulon J, Sasser G, Taverne MAM, Varga J, Baltusen R, Schekk Gy: Comparison of ultrasonography, bovine pregnancy-specific protein $B$, and bovine pregnancyassociated glycoprotein I test for pregnancy detection in dairy cows. Theriogenology 1998, 50:77-88.

14. Breukelman SP, Reinders JMC, Jonker FH, de Ruigh L, Kaal LMTE, van Wagtendonke-de Leeuw AMW, Vos PLAM, Dieleman SJ, Beckers JF, Perenyi Zs, Taverne MAM: Fetometry and fetal heart rates between day 35 and 108 in bovine pregnancies resulting from transfer of either MOET, IVP-co-culture or IVP-SOF embryos. Theriogenology 2004, 6 I:867-882.

15. Forsberg M, Tagle R, Madej A, Molina JR, Carlsson M-A: Radioimmunoassay of bovine, ovine and porcine luteinizing hormone with a monoclonal antibody and a human tracer. Acta vet scand 1993, 34:255-262.

16. Granström E, Kindahl H: Radioimmunoassay of the major plasma metabolite of PGF $_{2 \alpha}$, I5-keto- I 3, I 4-dihydro-PGF ${ }_{2 \alpha}$. In Methods in Enzymology Volume 86. Edited by: Lands WEM, Smith WL. New York: Academic Press Inc; 1982:320-339.

17. Greenwood FC, Hunter WM, Glover GS: The preparation of I3 II-labelled human growth hormone of high specific radioactivity. Biochem J 1963, 89:। |4-I23. 
18. Szenci O, Beckers JF, Sulon J, Bevers MM, Börzsönyi L, Fodor L, Kovacs F, Taverne MAM: Effect of induction of late embryonic mortality on plasma profiles of pregnancy associated glycoprotein I in heifers. Vet J 2003, I65:307-3I3.

19. Madej A, Kindahl H, Larsson K, Edqvist L-E: Sequential hormonal changes in the postpartum dairy cow. Acta vet scand 1986, 27:280-295.

20. Lamond DR, Tomlinson RV, Drost M, Henricks DM, Jöchle W: Studies of prostaglandin $\mathbf{F}_{2 \alpha}$ in the cow. Prostaglandins 1973, 2:269-284

21. Kindahl H, Edqvist LE, Bane A, Granström E: Blood levels of progesterone and I5-keto-13, I4-dihydro-prostaglandin $F_{2 \alpha}$ during the normal oestrous cycle and early pregnancy in heifers. Acta endocrinologica 1976, 82:134-149.

22. Bekana M, Odensvik K, Kindahl H: Prostaglandin $\mathbf{F}_{2 \alpha}$ metabolite and progesterone profiles in postpartum cows with retained foetal membranes. Acta vet scand 1996, 37:171-185.

Publish with Bio Med Central and every scientist can read your work free of charge

"BioMed Central will be the most significant development for disseminating the results of biomedical research in our lifetime. "

Sir Paul Nurse, Cancer Research UK

Your research papers will be:

- available free of charge to the entire biomedical community

- peer reviewed and published immediately upon acceptance

- cited in PubMed and archived on PubMed Central

- yours - you keep the copyright 